\title{
E3 Ubiquitin/ISG15 Ligase TRIM25
}

National Cancer Institute

\section{Source}

National Cancer Institute. E3 Ubiquitin/ISG15 Ligase TRIM25. NCI Thesaurus. Code C21251.

E3 ubiquitin/ISG15 ligase TRIM25 (630 aa, 71 kDa) is encoded by the human TRIM25 gene. This protein is involved in both innate immunity and protein ubiquitination. 